\title{
References:
}

1. Ilchenko, A. (2014). Vishha osvita i Bolonskij proczes: Navchalno-metodichnij posibnik [Higher education and the Bologna process: Textbook]. Poltava: RVV PDAA, 316 p. (in Ukrainian)

2. Artyomov, I. (2015). Innovacziyi v osviti i nauczi okremikh krayin Yevropi, Aziyi ta Ameriki [Innovations in education and science of individual countries of Europe, Asia and America]. Uzhgorod, 205 p. (in Ukrainian)

\section{ELECTRONIC CONTENT OF DISTANCE LEARNING IN HIGHER EDUCATION}

\section{Oksana Ivanova ${ }^{1}$ \\ Olena Krekoten $^{2}$}

DOI: https://doi.org/10.30525/978-9934-588-39-6-6

With the rapid technological development of society, there is a constant need to solve complex problems quickly and effectively. Therefore, using high-tech teaching methods, such as electronic educational resources, is of acute importance nowadays.

Knowledge goes out of data every 3-5 years, technological knowledge becomes obsolete every 2-3 years. With a little more time it will be 1, 5-2 years. As for content knowledge of graduates, it doubles every 3-4 years. If educational technologies are not changed, the quality of specialists' training will lag far behind the level needed in the labour market [1]. Society has a requirement in personality, able to self-education. Nowadays, the words «study» and "work» have become synonyms, united in the distance learning mode.

Distance learning is a set of technologies providing students with main teaching support materials, the interactive cooperation of students with their teacher in the training process, giving students the opportunity to work with educational materials both individually and during the training process. Different methods of providing educational information can be used in distance learning [1].

In recent years, the number of people studying on non-traditional technologies has grown rapidly. The long-term aim of distance learning development all over the world is to give opportunity to every student living anywhere to take a learning course of any educational establishment

\footnotetext{
${ }^{1}$ Sumy National Agrarian University, Ukraine

${ }^{2}$ Sumy National Agrarian University, Ukraine
} 
according to his choice. It means the transition from the concept of physical removal of students from country to country towards a new concept of mobile ideas, knowledge and learning in order to share knowledge by learning resources exchange.

Educational electronic content of new generation takes into account all relevant indicators. Being one of the adopters of distance learning technologies, Sumy National Agrarian University traditionally has focused on students' international farming practices, their opportunities of being able to work and to study at the same time. As for distance learning systems of chemistry and foreign languages for professional purposes, they are based on such means of «electronic studies» as: use of e-lecturers, electronic practical work, virtual laboratory, simulators, on-line textbooks and encyclopaedias, sets of integrated results-based training materials, processes and events simulations (reproduction of complex chemical experiments or some professional language situations), multimedia content, chat sessions, Moodle training, interactive teleconferencing, creation of testing students control systems (use of controlling program Test-2002), application of Kahoot program for quizzes, tests and surveys creation, use of electronic log, e-mail and Internet, mastering skills in solving typical tasks and creating professional projects in foreign language, control and data processing of chemical experiments.

The problem of creation, development and use of special tools for students' competence assessment, as well as the key terms definition should be seen as especially actual in the teaching process. Tests are used to organize students' self-control, the ongoing and resulting integrated monitoring both in Chemistry and in Foreign Language for Professional Purposes. Via online training, the outcome of each answer involves a corresponding comment. Via results-based monitoring, the student can see only the overall result, with a full analysis of the test available to the teacher. Various types of tasks, such as: "yes» or «no», relevance or text content questions can be used to test students' knowledge.

E-learning-module technology allows the distance learning in the Moodle system, based on the active use of various information, technological and technical means that makes the learning process possible without taking into consideration neither time nor place. The most significant attributes of distance learning are flexibility, modularity, parallelism, completeness of information access, economic and technological effectiveness, internationality and humanity. Computer-based educational systems provide the ability to differentiate the learning process, to apply an individual approach, to monitor students' mistakes and to carry out a feedback, to provide self-control and self-monitoring of educational and cognitive activity, to save time by 
performing complex calculations on the computer, to demonstrate visual educational information, to simulate processes and events, to carry out the laboratory training, experiments and research in virtual reality, to develop decision-making skills etc. It is important to recognise the power of basic facilities which allow improving the students' professional skills and qualities.

\section{References:}

1. Corbut, O. G. (2015). Dystancijne navchannja: modeli, tekhnologhiji, perspektyvy [Distance learning: models, technologies, perspectives] (unpublished). Proceedings of the XI Mizhnarodna naukovo-praktychna konferencija «Suchasni tendenciji vykladannja inozemnoji movy profesijnogho sprjamuvannja u vyshhij shkoli» (Ukraine, Kyiv, April 29,2015). Retrieved from: http://confesp.fl.kpi.ua/ ru/node/1123 (accessed March 18, 2020).

2. Huz, O. I. (2016). Khimichnyj eksperyment - odyn iz metodiv navchannja u vyshhij shkoli [Chemical experimentation is one of the methods of teaching in higher education]. Proceedings of the Mizhnarodnoji naukovo-praktychnoji konferenciji «Metodyka navchannja pryrodnychykh dyscyplin u serednij ta vyshhij shkoli» (XXIII Karyshynsjki chytannja) (Ukraine, Poltava, May 19-20, 2016). Poltava:PDATU, pp. 110-112.

3. Pushkaryova, T. O. (2011). Elektronnyj kontent: osoblyvosti zastosuvannja i novi mozhlyvosti piznannja svitu [Electronic Content: Application Features and new possibilities of knowing the world]. Komp'juter u shkoli ta sim'ji, no. 4, pp. 7-10.

4. Tereshchenko, T. E., Polovnikova, S. Yu., Pyatakha, G. G., Romanov, O. V., \& Vlasova, Yu. Yu. (2000). Aktyvni metody navchannja [Active teaching methods]. Dnepropetrovsk: DDFEI. (in Ukrainian) 